\title{
SEMINAR DAN PELATIHAN TENTANG DAUR ULANG SAMPAH PLASTIK DI DUTASIA LEARNING TANGERANG \\ Wahyu Irawati ${ }^{1}$, Georgine Gladis Paula Sulardi ${ }^{2}$, Grace Charity Mary Cartir ${ }^{3}$, Greisnaningsi ${ }^{4}$ \\ ${ }^{1,2,3,4}$ Program Studi Pendidikan Biologi, Fakultas Ilmu Pendidikan, Universitas Pelita Harapan
}

wahyu.irawati@uph.edu, georginegladis24@gmail.com, mary.charitygrace@gmail.com, greisnaningsi10@gmail.com

\begin{abstract}
Abstrak
Sampah plastik merupakan produk samping dari aktivitas manusia sehari-hari yang apabila tidak dikelola dengan baik akan menimbulkan permasalahan lingkungan. Pengabdian kepada Masyarakat dilaksanakan di Dutasia Learning, Jl. Gandasari No. 45, Gandasari, Kecamatan Jatiuwung, Dumpit, Tangerang, Banten 15810. Analisis situasi di Dutasia Learning menunjukkan bahwa warga Dutasia memiliki sedikit keterbatasan pada kesadaran akan peduli lingkungan. Banyak warga terutama anak-anak membuang plastik di sembarang tempat sehingga tampak adanya tumpukan plastik di beberapa lokasi. Pengabdian kepada Masyarakat ini bertujuan untuk melakukan seminar dan pelatihan tentang peran daur ulang sampah plastik dalam pelestarian lingkungan. Seminar disertai dengan pelatihan pembuatan prodak daur ulang plastik menjadi produk yang bermanfaat. Acara berlangsung selama dua jam dihadiri oleh 35 warga Desa Dumpit terdiri atas remaja dan anak-anak. Hasil kegiatan ini berupa barang hasil pelatihan pembuatan daur ulang berupa dompet plastik dan kotak pensil dari botol air mineral. Sejumlah 25 anak berhasil menyelesaikan pembuatan kotak pensil, tiga anak berhasil menyelesaikan dompet plastik, serta sisanya menyelesaikannya di rumah. Melalui kegiatan PkM ini diharapkan warga Dutasia mempunyai wawasan baru agar menggunakan plastik seperlunya, menggunakan kembali plastik yang masih bisa digunakan untuk keperluan lain, serta membuat daur ulang sampah plastik menjadi produk yang bermanfaat.
\end{abstract}

Kata Kunci : Daur ulang, lingkungan, plastik, produk, sampah.

\section{PENDAHULUAN}

Lingkungan yang dicemari oleh sampah saat ini dapat dengan mudah kita temukan di sekitar kita. Pencemaran lingkungan dengan limbah sampah adalah salah satu contoh nyata bahwa manusia telah gagal menjalankan perintah Allah untuk memelihara dan mengelola alam. Aktivitas manusia pada umumnya akan menghasilkan limbah, karena itu jumlah penduduk akan mempengaruhi jumlah sampah yang dihasilkan (Amasuomo \& Baird, 2016). Peningkatan jumlah sampah, salah satunya sampah plastik akan menjadi masalah lingkungan jika tidak segera diatasi.

Kesadaran yang rendah terhadap lingkungan serta dampak yang ditimbulkan karena menumpuknya sampah membuat masyarakat tidak secara bijak menggunakan plastik, sehingga menimbulkan masalah baru yaitu penumpukkan sampah plastik. Salah satu daerah yang memiliki masalah dengan sampah plastik yaitu Dutasia. Warga Dutasia memiliki sedikit keterbatasan pada kesadaran akan peduli lingkungan. Banyak warga terutama anak-anak yang tidak bisa membedakan sampah organik dan non-organik serta membuang sampah tidak pada tempatnya. Sampah dibagi menjadi dua jenis yaitu sampah organik dan non organik, sampah organik adalah limbah yang asalnya dari makhluk hidup yang dapat mengalami pembusukan, sedangkan sampah non organik adalah sampah yang berasal dari limbah manusia yang sulit untuk diurai oleh bakteri, sehingga membutuhkan waktu yang lama untuk diurai (Taufiq \& Maulana, 2015). 
Warga sering menggunakan plastik tanpa menyadari dampak negatif dari akumulasi sampah plastik. Dampak negatif yang sering timbul utamanya itu berkaitan dengan kesehatan. Dampak negatif penggunaan sampah plastik bagi kesehatan yaitu dapat menimbulkan gangguan kesehatan seperti menyebabkan kanker, gangguan kehamilan, dan kerusakan jaringan tubuh lainnya pada manusia (Gunadi, Parlindungan, Santi, Aswir, \& Aburahman, 2020). Warga membuang plastik di sembarang tempat sehingga timbulnya tumpukan plastik di beberapa lokasi. Semakin meningkatnya sampah di lingkungan Dutasia Learning dapat menjadi masalah serius bila tidak dicari penyelesaiannya. Oleh sebab itu, salah satu langkah efektif dalam mengurangi sampah plastik adalah dengan melakukan daur ulang sampah plastik (Dirgantara, 2013).

Penanganan sampah plastik yang popular selama ini adalah dengan 3R (Reuse, Reduce, Recycle) (Agus, Oktaviyanthi, \& Sholahudin, 2019). Reuse adalah memakai berulang kali barangbarang yang terbuat dari plastik. Reduce adalah mengurangi pembelian atau penggunaan barangbarang dari plastik, terutama barang-barang yang sekali pakai. Recycle adalah mendaur ulang barangbarang yang terbuat dari plastik. Plastik mempunyai banyak keunggulan karena kuat, ringan, fleksibel, tahan karat, tidak mudah pecah, mudah diberi warna, mudah dibentuk, serta isolator panas dan listrik yang baik sehingga limbah plastik memiliki banyak keunggulan jika dapat dimanfaatkan menjadi produk daur ulang (Putra \& Yuriandala, 2010). Berdasarkan pemaparan masalah di atas, tujuan dari penulisan makalah ini adalah agar warga Dutasia Learning: 1) dapat menyadari dampak timbunan limbah sampah plastik; 2) dapat mendaur ulang sampah plastik menjadi produk daur ulang yang bermanfaat.

\section{METODE}

Metode kegiatan pengabdian kepada masyarakat $(\mathrm{PkM})$ yang digunakan adalah metode ceramah (seminar) dan pelatihan. Kegiatan PkM berupa pelatihan peran daur ulang sampah plastik dalam pelestarian lingkungan dilaksanakan di halaman rumah Ibu Heni, Koordinator Dutasia Pos Belajar Dumpit, J1. Gandasari No. 45, Gandasari,
Kecamatan Jatiuwung, Kota Tangerang, Banten 15810. Kegiatan dilaksanakan pada hari Rabu, 26 Juni 2019. Kegiatan di mulai pukul 10.00 WIB dengan dihadiri oleh 34 orang peserta. Bentuk kegiatan di Dutasia Learning meliputi dua tahapan. Tahap pertama adalah seminar tentang peran daur ulang sampah plastik dalam pelestarian lingkungan. Tahap kedua adalah pelatihan pembuatan produk daur ulang dari sampah plastik. Kegiatan diawali dengan doa pembukaan yang dibawakan oleh Ibu Wahyu Irawati yang sekaligus berperan sebagai pembicara dalam pelatihan tersebut. Pembicara mengawali pelatihan dengan menyampaikan latar belakang dilaksanakannya PkM.

Pembicara menyampaikan bahwa sampah pada umumnya terdiri dari sampah plastik dan sampah kertas yang merupakan bahan buangan dari manusia. Sampah dapat menjadi masalah sosial karena berpotensi menimbulkan pencemaran lingkungan dan berbahaya ketika terjadi banjir dan air pasang laut serta dapat berdampak bagi kesehatan manusia (Karuniastuti, 2019) Akumulasi dari persoalan ini akan mengakibatkan rendahnya kesehatan masyarakat. Oleh karena itu, dengan cara daur ulang sampah dapat mengatasi masalah yang terjadi di lingkungan. Pembicara menyampaikan tujuan dilaksanakannya PkM adalah agar masyarakat menyadari dampak timbunan limbah sampah plastik sehingga masyarakat dengan sadar mengurangi penggunaan plastik. Kegiatan ini juga bertujuan agar masyarakat dapat mendaur ulang sampah plastik menjadi produk daur ulang yang bermanfaat.

Pembicara juga menjelaskan bahwa Allah menciptakan lingkungan dengan teratur dan kompleks dan Allah memberikan mandat budaya kepada manusia untuk menjaga dan mengelola lingkungan yang telah diciptakan. Selanjutnya, pembicara menjelaskan bahwa manusia telah jatuh dalam dosa dan mengakibatkan manusia tidak dapat menjalankan mandat budaya tersebut dengan baik, sehingga terjadi kerusakan lingkungan sebagai dampak terjadinya pencemaran. Manusia dalam ketidaktaatannya merusak dan mengeksploitasi lingkungan seperti membuang sampah sembarangan tanpa mengelolanya sehingga terjadi pencemaran tanah.

Pencemaran terbesar dan berbahaya bagi kesehatan manusia dan lingkungan adalah pencemaran plastik. Sampah plastik berbahaya 
karena plastik tidak dapat didegradasi di lingkungan. Plastik terdiri atas polimer, yaitu rantai panjang atom yang mengikat satu sama lain. Rantai ini membentuk banyak unit molekul berulang, atau "monomer" biasanya 500-20.000 monomer (Kamsiati, Herawati, \& Purwani, 2017). Plastik terdiri dari polimer karbon saja atau dengan oksigen, nitrogen, klorin yang menghubungkan unit monomer menjadi kesatuan yang tak terpisahkan.

Pembicara juga menyampaikan bahwa Allah setia melakukan pemeliharaan terhadap umatnya dengan memberikan hikmat kepada manusia untuk mengatasi pencemaran plastik yaitu dengan menciptakan plastik biodegradable yaitu dapat didegradasi oleh bakteri yaitu berasal dari bahan pati

singkong dan khitosan (Astuti, Kusuma, \& Kumila, 2019). Cara mengatasi pencemaran plastik juga dapat dilakukan dengan tindakan 3R yaitu Reduce, Reuse, Recycle. Pembicara menekankan cara penanggulangan sampah plastik yang dapat dilakukan oleh warga Dutasia Learning adalah melakukan daur ulang sampah. Daur ulang sampah adalah cara untuk mengurangi volume sampah dilingkungan dengan mengelolanya menjadi barang berguna dan bernilai jual. Cara daur ulang sampah yang disampaikan meliputi daur ulang sampah plastik menghasilkan barang berguna seperti tempat pensil, dompet dan barang lainnya.

Pelatihan ini dilanjutkan dengan praktik secara langsung mengenai tahap-tahap daur ulang sampah plastik menjadi dompet dan tempat pensil. Warga dibagi menjadi tujuh kelompok dimana masing-masing didampingi oleh mahasiswa UPH yang ikut membantu pelaksanaan PkM dan bertugas sebagai mentor (gambar 1). Mahasiswa UPH membagikan alat dan bahan yang akan digunakan dalam kegiatan tersebut, kemudian menjelaskan fungsi dari masing-masing alat dan bahan. Alat dan bahan yang digunakan yaitu, jarum, gunting, spons, benang, lem, sampah plastik, cutter, pensil, penggaris, jangka besar, kertas bekas, cat warna, lem, kardus bekas, aksesoris tambahan. Langkahlangkah daur ulang yaitu, menyiapkan alat dan bahan dan membuat barang daur ulang sesuai dengan alat dan bahan yang ada. Mahasiswa dalam setiap kelompok juga menjelaskan cara membuat dompet dari plastik bekas dan tempat pensil dari botol air mineral. Setiap warga ikut melakukan daur ulang sesuai dengan tahap-tahap yang sudah dijelaskan hingga menghasilkan produk daur ulang. Pembicara ikut memantau jalannya pelatihan tersebut dengan cara berkeliling dari satu kelompok ke kelompok berikutnya.

Pembuatan dompet dari sampah plastik menggunakan sampah plastik kemasan, jarum, benang, gunting, spons pencuci piring, dan resleting. Cara kerja pembuatan dompet dari sampah plastik kemasan terdiri dari beberapa tahap yaitu: 1) alat dan bahan disediakan; 2) sampah plastik kemasan dibersihkan dari kotoran menggunakan spons; 3) bagian atas dan bawah sampah plastik kemasan digunting; 4) bagian atas sampah plastik dijahit agar menyatu dengan resleting (posisi sampah plastik dan yang bergambar bisa ada di bagian dalam); 5) sisi kiri, kanan dan bahwa sampah plastik dijahit hingga tertutup semua sisi; 6) tahap terakhir sampah plastik yang telah dijahit bisa dibalik posisi nya dengan sisi bergambar berada di depan (gambar 2). 
Peserta mendengarkan penyampaian seminar dari pembicara

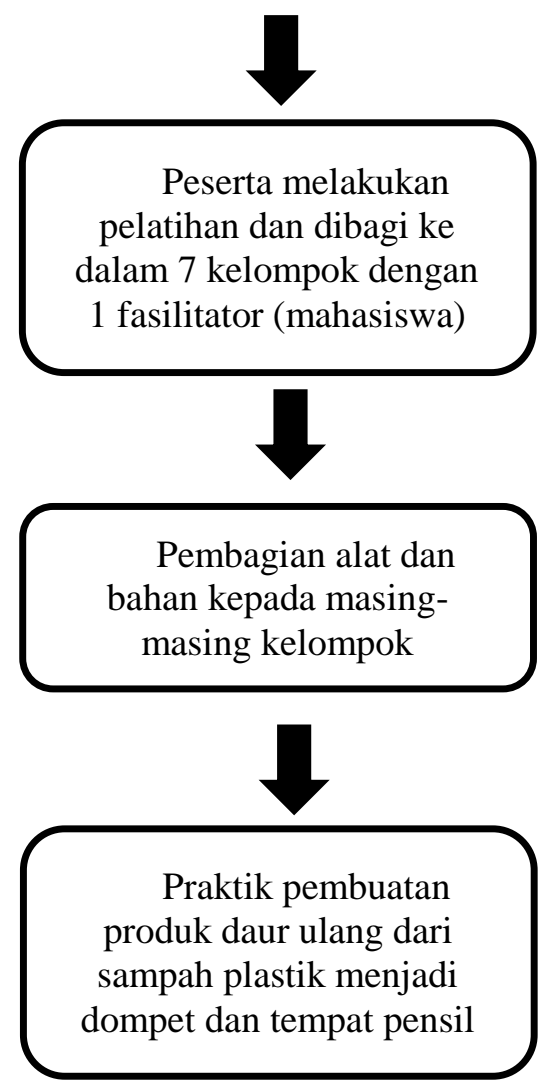

Gambar 1. Tahapan pelaksanaan pelatihan kegiatan PkM daur ulang sampah plastik
Menyiapkan alat dan bahan berupa sampah plastik kemasan, jarum, benang, gunting, spons pencuci piring, dan menggunakan spons

Menggunting bagian atas dan bawah sampah plastik kemasan

Menjahit bagian atas sampah plastik agar menyatu dengan resleting dengan posisi sampah plastik yang bergambar ada di bagian dalam

Menjahit semua sisi kiri, kanan dan bahwa sampah plastik hingga tertutup semua sisi

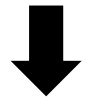

Membalikan posisi sampah plastik yang telah dijahit bisa sehingga sisi bergambar berada di depan

Gambar 2. Tahap-tahap pembuatan dompet dari sampah plastik kemasan

Pembuatan tempat pensil dari sampah plastik menggunakan sampah botol plastik bekas, resleting, 
lem tembak, spons pencuci piring dan beberapa hiasan. Cara pembuatan tempat pensil dari sampah botol plastik bekas melalui beberapa tahap yaitu: 1) alat dan bahan disiapkan; 2) botol plastik bekas dibersihkan menggunakan spons; 3) botol digunting menjadi dua bagian disesuaikan dengan ukuran yang dingingkan; 4) resleting ditempelkan dibagian tepi dari botol menggunakan lem tembak; 5) resleting dibuka dan kemudian ditempelkan satu sisi lain dari resleting sampai kedua bagian botol tersambung; 6) tempat pensil dari botol plastik bekas siap digunakan dan bisa ditambahkan hiasan sesuai selera (gambar 3).

Pelatihan ini diakhiri dengan foto bersama dan pemberian cindera mata dari UPH kepada warga. Pembicara menyampaikan ucapan terima kasih kepada warga atas waktu dan kesempatan yang diberikan sehingga PkM dapat berjalan dengan baik. Pembicara juga memberikan pesan agar semakin mencintai lingkungan dengan cara menerapkan pelatihan yang sudah diberikan sebagai bentuk pertanggungjawaban warga dalam melaksanakan mandat budaya untuk memelihara ciptaanNya. Kegiatan PkM ditutup dengan doa dan makan siang bersama.

Menyiapkan alat dan bahan berupa sampah botol plastik bekas, resleting, lem tembak, spons pencuci piring dan beberapa hiasan

Membersihkan sampah botol plastik bekas menggunakan spons

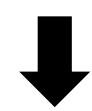

Menggunting botol bekas menjadi dua bagian disesuaikan dengan ukuran yang dingingkan

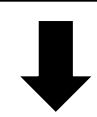

Menempelkan resleting di bagian tepi dari botol menggunakan lem tembak

\section{Gambar 3. Tahap-tahap pembuatan tempat pensil dari sampah botol plastik bekas.}

\section{HASIL DAN PEMBAHASAN}

Kegiatan PkM berupa pelatihan Peran Daur Ulang Sampah Plastik Dalam Pelestarian Lingkungan dilaksanakan di halaman rumah Ibu Heni, Koordinator Dutasia Pos Belajar Dumpit, Jl. Gandasari No. 45, Gandasari, Kecamatan Jatiuwung, Kota Tangerang, Banten 15810. Kegiatan dilaksanakan pada hari Rabu, 26 Juni 2019. Kegiatan di mulai pukul 10.00 WIB dengan dihadiri oleh 35 orang peserta.

Kegiatan PkM diawali dengan menyampaikan latar belakang dilaksanakannya kegiatan yaitu untuk menjalankan misi Universitas Pelita Harapan, yaitu berkontribusi pada kemajuan ilmu pengetahuan dan kebudayaan yang dipimpin oleh wawasan dunia Kristen yang Alkitabiah serta berpartipasi secara redemtif dalam pengembangan individu dan masyarakat bagi kemuliaan Allah. Kegiatan dilanjutkan dengan penyampaian informasi tentang sampah terkhususnya sampah plastik.

Bentuk kegiatan PkM di Dutasia Learning meliputi dua tahapan. Tahap pertama adalah seminar tentang peran daur ulang sampah plastik dalam pelestarian lingkungan dan tahap kedua adalah pelatihan pembuatan produk daur ulang dari sampah plastik. Target yang ingin dicapai melalui pelaksanaan kegiatan plastik yaitu warga sekitar pos belajar Dutasia Dumpit dapat memahami dan menyadari dampak timbunan limbah sampah plastic sehingga mengurangi penggunaan plastik serta masyarakat dapat mendaur ulang sampah plasti menjadi produk daur ulang yang bermanfaat.

\section{Daur Ulang Sampah Plastik}

Warga yang tinggal disekitar pos belajar Dutasia Dumpit masih memiliki pengetahuan yang rendah dalam mengelola sampah plastik menjadi produk yang bermanfaat dan bernilai jual, sehingga pada beberapa titik di sekitar tempat tinggal warga terdapat tumpukan sampah plastik. Oleh karena itu, PkM yang dilakukan di pos belajar Dutasia Dumpit ialah pelatihan untuk mendaur ulang sampah plastik menjadi produk bermanfaat. Daur ulang merupakan pengolahan kembali barang yang dianggap tidak memiliki manfaat menjadi produk yang bermanfaat melalui proses fisik atau kimiawi, atau keduanya 
bergantung pada produk yang ingin dihasilkan (Purwaningrum, 2016). Kegiatan PkM memberikan pelatihan kepada warga untuk memanfaatkan sampah berupa botol plastik maupun plastik bekas snack, deterjen, pewangi dan lain-lain menjadi barang berguna. Misalnya tempat pensil, dompet, tas kecil dan lain sebagainya.

Peserta dibagi menjadi tujuh kelompok dimana masing-masing didampingi oleh mahasiswa UPH yang ikut membantu pelaksanaan PkM dan bertugas sebagai mentor. Setiap mentor bertugas menjelaskan tahap-tahap dalam melakukan daur ulang sampah. Peserta diberi kesempatan untuk bergabung bersama kelompok lain untuk mendengar dan melihat penjelasan dari kelompok tersebut.

\section{a. Tempat Pensil dari Botol Plastik Bekas}

Daur ulang sampah plastik yang pertama adalah dari botol plastik bekas. Hal pertama yang dilakukan oleh mahasiswa UPH ialah membagikan alat dan bahan yang akan digunakan dalam kegiatan tersebut kemudian menjelaskan fungsi dari masingmasing alat dan bahan (gambar 4). Alat dan bahan yang digunakan yaitu, gunting, lem, botol plastik bekas, cutter, pensil, penggaris, cat warna, lem, dan aksesoris tambahan. Setelah penjelasan alat dan bahan, mahasiswa UPH mendemonstrasikan langkah-langkah pembuatan daur ulang botol plastik menjadi tempat pensil. Setelah itu, warga Dutasia bersama-sama membuat tempat pensil dari botol plastik sesuai dengan tahap-tahap yang sudah dijelaskan hingga menghasilkan produk daur ulang tempat pensil dari botol plastik bekas (gambar 5).

Hasil dari daur ulang botol plastik bekas adalah tempat pensil yang memiliki fungsi yang sama dengan tempat pensil pada umumnya. Namun, hasil dari daur ulang botol plastik ini memiliki keunikannya yaitu berbentuk botol panjang sesuai botol yang digunakan sehingga pensil, pulpen, dan alat tulis lainnya dapat dimasukkan ke dalam tempat pensil tersebut. Selain itu, tempat pensil tersebut dapat dihias dengan menarik sesuai dengan kekreatifitasan sendiri sehingga bisa memiliki nilai jual.

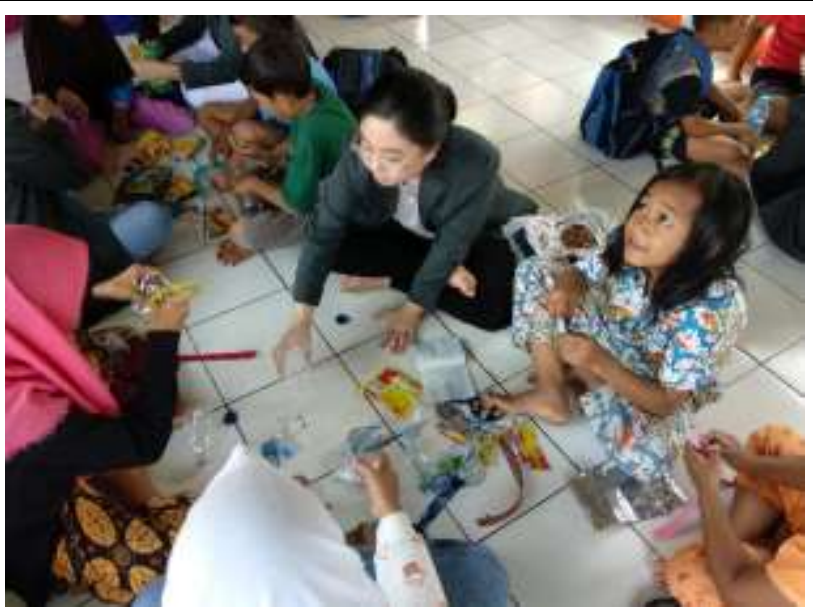

Gambar 4. Penjelasan alat dan bahan

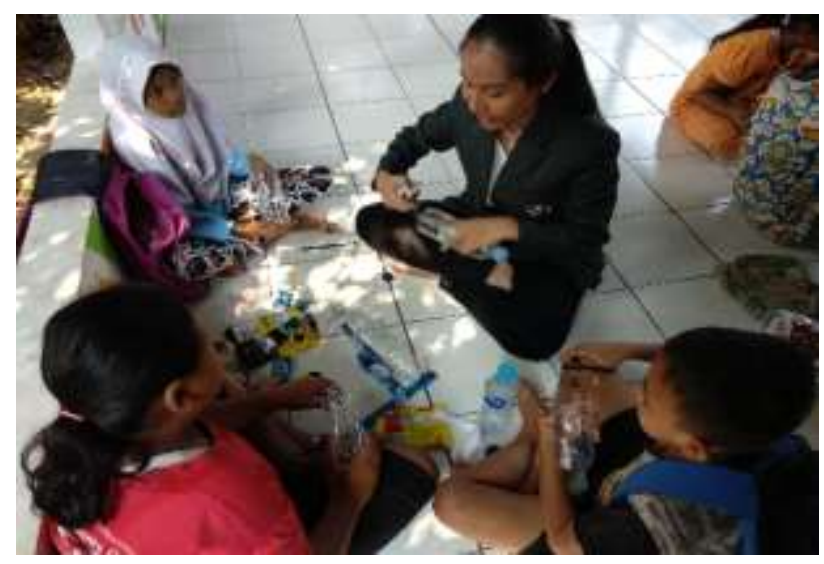

Gambar 5. Pembuatan tempat pensil dari botol air bekas

\section{b. Dompet dari Sampah Plastik}

Daur ulang sampah plastik yang kedua adalah pembuatan dompet dari sampah plastik kemasan. Hal pertama yang dilakukan adalah membagi alat dan bahan yang digunakan dalam setiap kelompok (gambar 6). Setelah itu mahasiswa UPH yang bertugas sebagai mentor menjelaskan setiap alat dan bahan, serta cara membuat dompet dari sampah plastik di dalam setiap kelompok. Alat dan bahan yang diperlukan untuk membuat dompet dari sampah plastik adalah sampah plastik berupa sampah kemasan seperti deterjen, snack, pewangi dan lain sebagainya, kemudian dibutuhkan juga gunting, jarum, spons, benang, dan resleting. Alat dan bahan tersebut mudah dicari dan memiliki harga yang terjangkau. Setelah tahap penjelasan alat 
dan bahan, mahasiswa UPH memberikan kesempatan kepada warga Dutasia untuk samasama membuat dompet dari sampah plastik sesuai penjelasan yang sudah diberikan (gambar 7). Selama pembuatan dompet, mahasiswa UPH memberikan kesempatan bagi warga Dutasia untuk bertanya seputar materi daur ulang sampah maupun pelatihan pembuatan produk dari sampah plastik.

Hasil akhir dari daur ulang sampah plastik kemasan adalah dompet yang memiliki fungsi yang sama dengan dompet pada umumnya. Produk dompet yang dihasilkan sangat unik, menarik dan bernilai jual. Produk dompet tersebut menarik karena sangat berwarna dan memiliki motif dan warna yang unik sesuai dengan sampah plastik kemasan yang digunakan

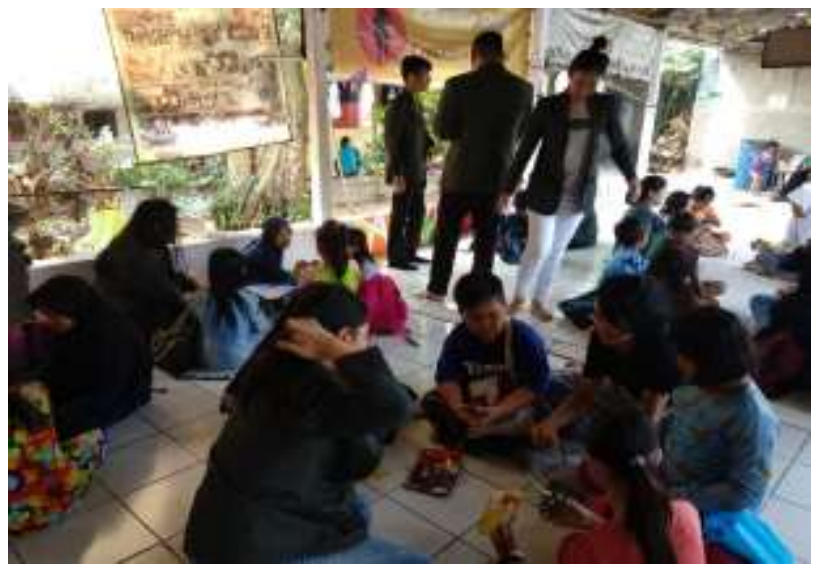

\section{Gambar 6. Pembagian alat dan bahan dalam pembuatan dompet dari sampah plastik}

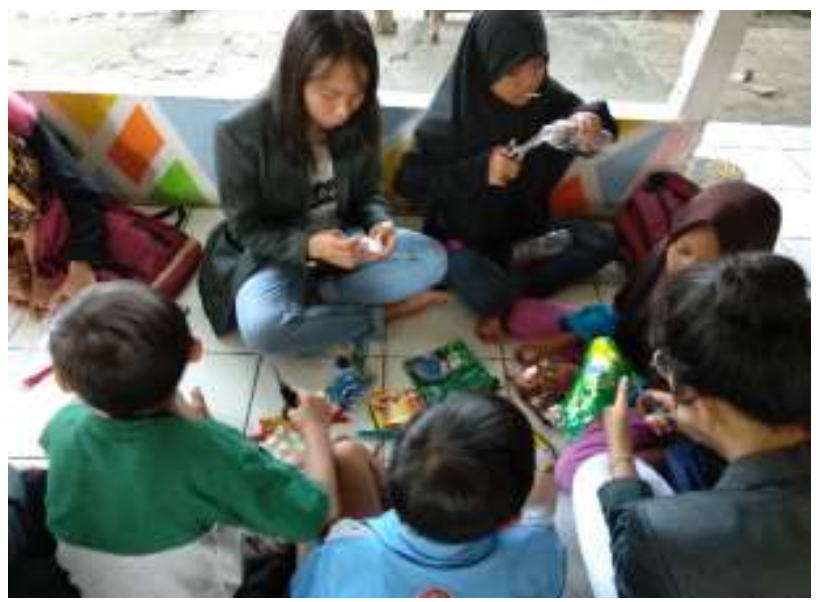

\section{Gambar 7. Pembuatan dompet dari sampah plastik}

Acara berlangsung selama dua jam yang dihadiri oleh 35 warga Dutasia Dumpit yang terdiri atas remaja dan anak-anak. Acara meliputi penyampaian materi dan praktik daur ulang sampah plastik. Selama praktik daur ulang sampah plastik menjadi dompet dan tempat pensil, mahasiswa UPH juga memberikan kesempatan bagi warga Dutasia untuk bertanya seputar materi daur ulang sampah maupun pelatihan pembuatan produk dari sampah plastik (gambar 8). Hasil kegiatan ini berupa barang dari praktik daur ulang berupa dompet plastik dan tempat pensil dari botol air mineral. Sejumlah 25 anak berhasil menyelesaikan pembuatan tempat pensil dan tiga anak berhasil menyelesaikan dompet plastik. Anak yang belum berhasil menyelesaikan pekerjaannya adalah sejumlah tujuh anak karena mereka masih kecil

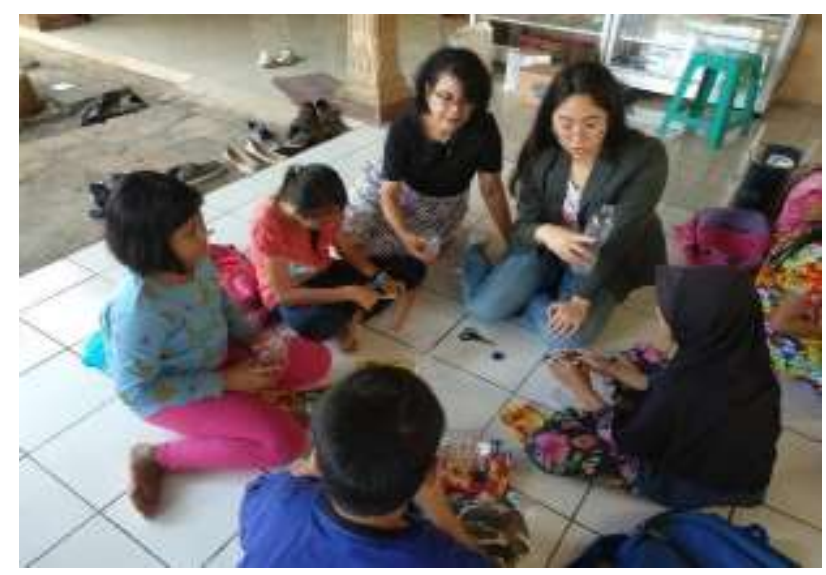

Gambar 8. Penjelasan dan tanya jawab dalam kelompok

Kegiatan PkM daur ulang sampah menjadi barang yang berguna ini memiliki potensi keberlanjutan. Potensi keberlanjutan program ini dilaksanakan melalui kerjasama tiga pihak yaitu antara warga, mahasiswa, dan dosen. Warga dapat terus menerapkan program daur ulang sampah menjadi barang berguna dengan bekal pengetahuan dan praktik yang sudah dilaksanakan bersama-sama. Selain itu, warga lebih mudah untuk melanjutkan program daur ulang tersebut, sebab alat dan bahan yang digunakan pada proses daur ulang sampah mudah ditemukan dan dibeli dengan harga yang 
terjangkau, sehingga warga dapat melakukan daur ulang sampah menjadi barang-barang yang berguna dan menunjang kehidupan.

\section{Evaluasi Hasil dan Dampak}

Kegiatan PkM yang sudah dilakukan membantu pemahaman warga tentang pentingnya mendaur ulang sampah, khususnya sampah plastik, dan cara untuk mendaur ulang sampah tersebut menjadi produk yang bermanfaat. Kegiatan seperti ini harus rutin dilakukan di Dutasia Learning agar lokasi tersebut dapat terhindar dari penumpukan sampah plastik. Melalui kegiatan daur ulang sampah ini tentunya berdampak baik bagi warga Dutasia. Dampak yang dimaksud yaitu: 1) warga semakin menyadari bahwa daur ulang sampah merupakan hal yang penting untuk diterapkan dalam kehidupan,

sebab hal tersebut merupakan tugas dan tanggung jawab manusia dalam mengelola lingkungan, 2) warga juga menyadari bahwa terdapat dampak negatif yang timbul akibat penumpukan sampah, 3) warga dapat membedakan berbagai jenis sampah, terutama yang ada di sekitar lokasi, 4) warga mendapat pengetahuan baru tentang cara mendaur ulang sampah menjadi barang yang berguna bahkan bernilai jual. Oleh karena itu, warga diharapkan untuk dapat menjalankan setiap proses yang ada dan tetap menikmatinya, terutama pada saat proses mendaur ulang sampah menjadi barang berguna.

Evaluasi dari pelatihan ini yaitu pelaksanaan pelatihan sudah baik dengan membagi warga ke dalam beberapa kelompok untuk penjelasan dan praktik pembuatan produk daur ulang dari sampah plastik. Warga sangat terbantu ketika setiap mahasiswa menjadi fasilitator di dalam setiap kelompok untuk memantau dan membantu warga apabila ada yang kebingungan atau kesulitan ketika melakukan praktik pembuatan produk daur ulang dari sampah plastik. Hal yang perlu diperhatikan untuk kedepannya yaitu mengenai pengumpulan sampah plastik kemasan dan botol bekas sebelum melakukan praktik bersama warga, karena itu merupakan bahan utamanya. Perlu memperhatikan jumlah peserta dengan jumlah bahan utama dalam pembuatan produk daur ulang dari sampah plastik kemasan dan botol bekas sehingga semua warga dapat kebagian dan bisa langsung mempraktekkan pada sesi praktik pembuatan bersama warga.

\section{KESIMPULAN}

Kesimpulan dari pelatihan ini adalah bahwa kegiatan PkM berupa seminar dan pelatihan dengan topik Peran Daur Ulang Sampah Plastik Dalam Pelestarian Lingkungan di Dutasia Learning warga Dumpit perlu dilakukan. Melalui kegiatan ini, warga semakin menyadari dampak negatif dari timbunan sampah plastik yang membahayakan lingkungan karena tidak dapat didegradari sehingga terdorong untuk mengurangi penggunaan plastik. Warga juga lebih menyadari bahwa dirinya mempunyai tugas dan tanggung jawab untuk menjalankan mandat budaya dalam memelihara lingkungan diantaranya

dengan memanfaatkan sampah untuk membuat produk daur ulang.

Saran yang dapat diberikan kepada warga di Dutasia Learning Dumpit untuk kedepannya setelah mengikuti seminar dan pelatihan ini adalah warga dapat mengumpulkan terlebih dahulu sampah plastik kemasan dan botol bekas sehabis menggunakanya, sehingga bisa langsung menerapkan pembuatan barang-barang yang bermanfaat sesuai dengan tahapan yang diberikan pada pelatihan. Warga juga bisa mengembangkan dengan lebih kreatif dan inovatif barang-barang bermanfaat yang dapat dibuat dengan sampah plastik kemasan dan botol plastik bekas. Contohnya dengan membuat produk lain yang bermanfaat dari sampah plastik kemasan dan botol bekas sehingga bisa digunakan sesuai fugsinya dan dapat dijadikan ide bisnis kedepannya. Penerapan pemanfaatan sampah plastik kemasan dan botol ini dapat mengatasi masalah pencemaran lingkungan dan warga semakin bisa bertanggungjawab untuk menjaga lingkungannya dengan membuat produk daur ulang dari sampah plastik. 


\section{UCAPAN TERIMAKASIH}

Ucapan terimakasih disampaikan kepada Lembaga Penelitian dan Pengabdian Masyarakat Universitas Pelita Harapan yang telah memberikan ijin dilaksanakannya kegiatan ini dengan No: PkM: PM-071-M/FIP/VI/2019PM-079-M/FIP/XI/2018.

Kegiatan ini dapat terlaksana berkat bantuan mahasiswa yang tergabung dalam Student Life yaitu Jessica Hans, Adrian, Arvent S, Felicia A, Felita G, dan Livia $M$, mahasiswa jurusan perhotelan Universitas Pelita Harapan.

\section{REFERENSI}

Agus, R. N., Oktaviyanthi, R., \& Sholahudin, U. (2019). 3R: Suatu Alternatif Pengolahan Sampah Rumah Tangga. Kaibon Abhinaya: Jurnal Pengabdian Masyarakat, 1, 72-76. doi:https://doi.org/10.30656/ka.v1i2.1538

Amasuomo, E., \& Baird, J. (2016). The Concept of Waste and Waste Management. Journal of Management and Sustainability, 6, 88-96. doi:10.5539/jms.v6n4p88

Astuti, A. W., Kusuma, H. H., \& Kumila, B. N. (2019). Pembuatan dan karakterisasi plastik biodegradable berbahan dasar ampas ubi kayu dan kulit udang. Al-Fiziya: Journal of Materials Science, Geophysics,Instrumentation and Theoretical Physics, 2, 119-128. doi:10.15408/fiziya.v2i2.12407

Dirgantara, I. M. (2013). Pengetahuan mendaur ulang sampah rumah tangga dan niat mendaur ulang sampah. Jurnal Studi Manajemen \& Organisasi, 10, 1-12. doi:https://doi.org/10.14710/jsmo.v10i1.5572
Gunadi, R. A., Parlindungan, D. P., Santi, A. U., Aswir, \& Aburahman, A. (2020). Bahaya plastik bagi kesehatan dan linkungan. Seminar Nasional Pengabdian Masyarakat LPPM UMJ, 1-7.

Kamsiati, E., Herawati, H., \& Purwani, E. Y. (2017). Potensi pengembangan plastik biodegradable berbasis pati sagu dan ubikayu di Indonesia. Jurnal Litbang Pertanian, 36, 67-76. doi:10.21082/jp3.v36n2.2017.p67-76

Karuniastuti, N. (2019). Bahaya plastik terhadap kesehatan dan lingkungan. Forum Teknologi, 03(1), 6-14.

Purwaningrum, P. (2016). Upaya Mengurangi Timbulan Sampah Plastik di Lingkungan. Jurnal Teknologi Lingkungan, 8, 141147.doi:http://dx.doi.org/10.25105/urbanenvirotech. v8i2.1421

Putra, H. P., \& Yuriandala, Y. (2010). Studi Pemanfaatan Sampah Plastik Menjadi Produk dan Jasa Kreatif. Jurnal Sains dan Teknologi Lingkungan, 2, 21-31. doi:https://doi.org/10.20885/jstl.vol2.iss1.art3

Taufiq, A., \& Maulana, M. F. (2015). SOSIALISASI SAMPAH ORGANIK DAN NON ORGANIK SERTA. Jurnal Inovasi dan Kewirausahaan, 68-73. 